\title{
Amphoterin-Induced Protein 2
}

National Cancer Institute

\section{Source}

National Cancer Institute. Amphoterin-Induced Protein 2. NCI Thesaurus. Code C119685.

Amphoterin-induced protein 2 (522 aa, 58 kDa) is encoded by the human AMIGO2 gene.

This protein plays a role in both the negative regulation of apoptosis and the mediation of cell-cell adhesion. 